\title{
Variscan accretionary complex of northwest Iberia: Terrane correlation and succession of tectonothermal events
}

\author{
José R. Martínez Catalán \\ Departamento de Geología, Universidad de Salamanca, 37008 Salamanca, Spain \\ Ricardo Arenas \\ Departamento de Petrología y Geoquímica, Universidad Complutense, 28040 Madrid, Spain \\ Florentino Díaz García \\ Departamento de Geología, Universidad de Oviedo, 33005 Oviedo, Spain \\ Jacobo Abati \\ Departamento de Petrología y Geoquímica, Universidad Complutense, 28040 Madrid, Spain
}

\begin{abstract}
The allochthonous terranes of northwest Iberia can be correlated with specific paleogeographic realms of the continental masses and intervening oceans involved in the Variscan collision. Assuming that the existing ophiolites represent the suture formed by the closure of the Rheic ocean, the units in the footwall to the suture correspond to the outer edge of the Gondwana continental margin, and the units in the hanging wall are interpreted as fragments of the conjugate margin, represented by the Meguma terrane. This correlation establishes a precise link between circum-Atlantic terranes, and makes it possible to draw a relatively simple scenario of the successive tectonothermal events recorded. Following the amalgamation of Avalon to Laurentia, the remaining outboard terranes underwent a progressive accretion to this continent that ended with the collision between Laurentia and Gondwana.
\end{abstract}

\section{INTRODUCTION}

The allochthonous terranes of northwest Iberia outcrop in five synforms or structural basins as megaklippen (Fig. 1), and consist of a pile of units, stacked in the first stages of the Variscan orogeny, during the Lower and Middle Devonian. The nappe pile was subsequently thnust, during the Upper Devonian-Lower Carboniferous, over a Paleozoic sedimentary sequence that forms the upper part of its relative autochthon (Marínez Catalán et al., 1996; Dallmeyer et al., 1997).

We outline a correlation of the allochthonous units of northwest Iberia with specific paleogeographic realms of the continental masses involved in the Variscan collision, as well as an intervening ocean, and describe their accretionary history, based mainly on the tectonothermal events recognized in the different units and on the isotopic age data available.

\section{DESCRIPTION OF UNITS}

The relative autochthon formed part of the continental margin of Gondwana during the Late Proterozoic and Paleozoic. This margin preserves evidence of the Cadomian (Pan-African) orogeny as well as of a Cambrian-Ordovician continental rifting process that resulted in the pulling apart of the Avalon microcontinent from the Gondwana mainland and the opening of the Rheic ocean (Cocks and Fortey, 1988). The extensional magmatic activity has been dated at 490-465 $\mathrm{Ma}$ (U-Pb on zircons: Lancelot et al., 1985; Gebauer, 1993).

For the allochthon, it is useful to classify their units into three groups, according to their relative position in the nappe pile: basal, intermediate, and upper units. Because the intermediate units show clear oceanic affinities, they are referred to as ophiolitic and are interpreted as the suture separating two paleogeographic realms.

The basal units consist of schists, paragneisses, and alternations of igneous felsic and mafic rocks. Granitic and peralkaline orthogneisses have yielded ages of 480-460 Ma (Van Calsteren et al., 1979, Rb-Sr whole rock; Santos Zalduegui et al., 1995, U-Pb on zircons). The magmatism reflects an Ordovician rifting episode (Ribeiro and Floor, 1987). Because there are no ophiolites separating them from their relative autochthon. the basal units are considered part of the continental margin of Gondwana. However, these units are considered to be allochthonous because there is a dramatic change in the metamorphic evolution between them and their relative autochthon. The basal units registered an initial highpressure metamorphic event, and are viewed as part of the external edge of Gondwana after the opening of the Rheic ocean, having undergone a westward subduction (in present coordinates) 380-370 m.y. ago, under an accretionary wedge consisting of a pile formed by the ophiolitic and upper units (Arenas et al., 1995; Martínez Catalán et al., 1996).

The ophiolitic units include basalts, pillowbreccias, diabases, metagabbros, plagiogranites, amphibolites, and ulramafics. They occur in several thrust sheets, and depict a wide variety of metamorphic grades, ranging from low-grade, high-pressure conditions to intermediate-pressure granulite, amphibolite and greenschist facies. The ophiolitic nappes were stacked during the closure of the Rheic ocean. The thrusts show east vergence, and the coeval amphibolite facies foliation was formed 390-380m.y. ago (Dalhneyer et al., $1991,{ }^{4} \mathrm{Ar} /{ }^{3} \mathbf{A r}$ on hornblende concenrates), closely following oceanic crust generation as young as $395 \mathrm{Ma}$ (Dunning et al., 1997, $\mathrm{U}-\mathrm{Pb}$ on aircons).

The upper unit sucturally overlie the ophiolites and can be subdivided into high-pressure and intermediate-pressure units. The highpressure units occupy the lower relative stuctural position. They consist of paragneisses and mafic and ulramafic rocks. The characteristic rocks are metabasites, commonly garnetclinopyroxene granulites and eclogites, retrograded to the amphibolite facies. Gabbros occur in several stages of ransformation, from virtually undeformed and unmetamorphosed, to coronitic metagabbros and high-pressure granulites. In the less-deformed gabbros, subophitic and diabase textures have been preserved, indicating an emplacement at relatively shallow levels. The chemical characteristics of the gabbros, comparable to modern continental tholeiites, are compatible with a continental rift provenance (Van Calsteren and Den Tex, 1978).

For the mafic rocks, Lower Ordovician ages, between 490 and 480 Ma (Peucat et al., 1990, $\mathrm{U}-\mathrm{Pb}$ on zircons), are considered to be protolith ages based on differentiation by cathodoluminescence of magmatic and metamorphic zircon domains (Schäfer et al., 1993, ion-microprobe 
Figure 1. Geologic map of northwest Iberia outlining allochthonous units and the megaklippen where they crop out: Cabo Ortegal, Ordenes, and Malpica-Tui in Spain, and Braganca and Morais in Portugal. For location, see Figure 2.

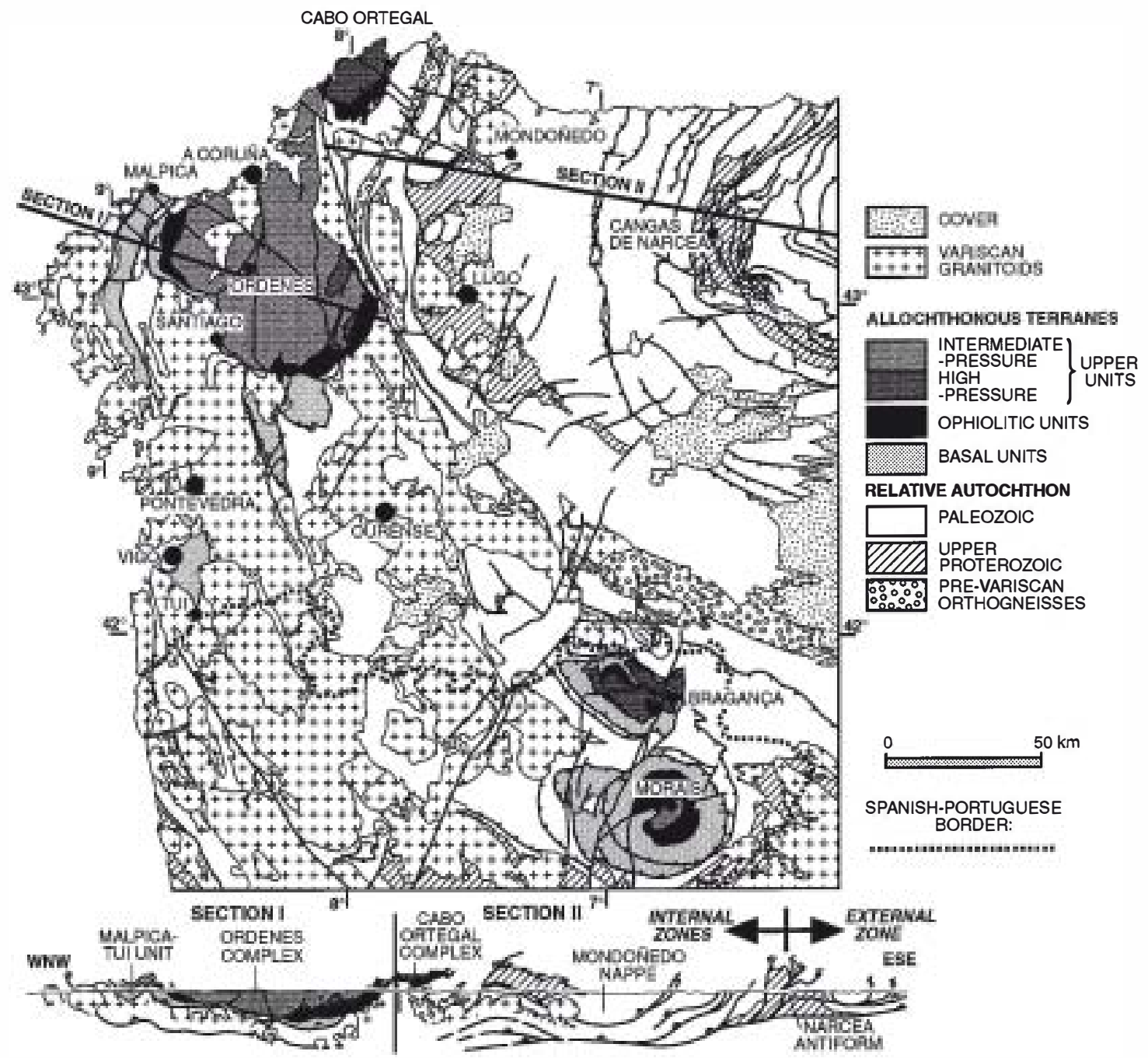

$\mathrm{U}-\mathrm{Pb})$. Based on the age of the youngest detrital zircon grain (507 Ma), Schäfer et al. (1993) suggested that at least part of the metasediments are younger than the Cambrian. The high-pressure metamorphism has been dated as between 405 and $390 \mathrm{Ma}$, and the subsequent retrograde amphibolite facies metamorphism is dated as 390-380 Ma (Schäfer et al., 1993; Santos Zalduegui et al., 1996, U-Pb on zircons, monazites, and titanites).

The overlying intermediate-pressure units include a very thick sequence of terrigenous metasedimentary rocks, large bodies of amphibolites, and intrusive augengneisses and gabbros. The augengneisses have yielded Lower Ordovician ages of 460-496 Ma (U-Pb on zircons: Kuijper, 1980; Dallmeyer and Tucker, 1993). The gabbros commonly have subophitic and diabase textures. The grade of metamorphism varies from the greenschist to the intermediate-pressure granulite facies.

\section{CORRELATION OF THE UPPER UNITS}

In a late Paleozoic reconstruction of Pangea (Lefort, 1989), western Iberia lies close to the
Grand Banks of Newfoundland (Fig. 2). The outermost terrane identified in the Appalachians of Maritime Canada is Meguma, the main component of which, the Meguma Group, consists of a thick sequence of as much as $10000 \mathrm{~m}$ of Cambrian-Ordovician detrital rocks, often turbiditic (Keppie and Dallmeyer, 1987). A Late Ordovician-Early Devonian bimodal volcanism was reported by Keppie and Dallmeyer (1987), and Dallmeyer and Keppie (1987) cited a 450 m.y. old granite (Rb-Sr whole rock).

A correlation can be established between the upper units in the allochthonous terranes of Iberia and Meguma. Both terranes include thick terrigenous successions with common flyschoid characteristics and ages, and registered a lower Paleozoic bimodal magmatism. Furthermore, the similarity in the oldest ages obtained from upper intercepts and inherited zircons from Meguma and the Iberian upper units, between 2.7 and 1.8 $\mathrm{Ga}$, reflects the provenance from a common source (Kuijper, 1980; Peucat et al., 1990; Krogh and Keppie, 1990; Dallmeyer and Tucker, 1993 Schäfer et al., 1993; Santos Zalduegui et al., 1995). These ages, also found in the orthogneisses of the relative autochthon (Lancelot et al., 1985; Gebauer, 1993), are similar to those of the west African craton, and point to a common Gondwanan basement for Meguma, the upper and basal units, and the relative autochthon of Iberia.

However, while the upper units are separated from the basal units and their autochthon by ophiolites, the Meguma terrane is in fault contact with the larger Avalon terrane, and no ophiolites occur between them. The thick detritic sequence that characterizes Meguma should be linked to a large emerged area. We suggest that Meguma may represent the southeastern continental margin of Avalon because of its position and also the age of its sediments, which fit the separation of Avalon from Gondwana in the Ordovician (Cocks and Fortey, 1988). Meguma is viewed as the conjugate rift pair of the Gondwana margin represented by the basal units and their autochthon in Iberia.

\section{ACCRETIONARY HISTORY}

The accretion of Avalon to Laurentia occurred probably during the early Silurian (Murphy et al., 1995), and the first cleavage in Meguma is dated 
as 415-390 Ma (Dallmeyer and Keppie, 1987). Surface geology and deep seismic reflection profiles show that Avalon was underthrust westward beneath the Laurentian plate, perhaps as much as 200 km (Hatcher, 1989; Quinlan et al., 1992).

In this context, the deformation in the upper units of the Iberian allochthonous terranes and, in particular, the subduction of some of them, probably reflects the continuous understacking of Avalonian and Meguma units toward the west following their accretion to Laurentia (Fig. 3). Because of their structural position, overlying the ophiolites, the high-pressure upper units are viewed as fragments of the outermost edge of Meguma (Fig. 3A). The subduction-related highpressure event occurre between 405 and $390 \mathrm{Ma}$ (Schäfer et al., 1993; Santos Zalduegui et al., 1996), and was coeval with deformation of the overlying accretionary wedge, of which Meguma was a part (Fig. 3B).

The high-pressure upper units underwent a decompressive episode during their emplacement onto the ophiolitic units. Synchronous amphibolite facies metamorphism, dated as $390-380 \mathrm{Ma}$, was retrogressive in the upper units and prograde in the underlying ophiolites. In the latter, this event reflects the westward subduction and understacking of the oceanic lithosphere related to the closure of the Rheic ocean (Fig. 3C). This closure was immediately followed by the subduction of the outer edge of Gondwana (Fig. 3D) because the end of the high-pressure event in the basal units has been dated as $374 \mathrm{Ma}$ (Van Calsteren et al., 1979, Rb-Sr on phengites). The westward polarity of this subduction has been deduced from the metamorphic gradient across the basal units (Martínez Catalán et al., 1996).

The continued underthrusting of continental crust induced the exhumation of the basal units, and was accompanied by the thinning of the overlying orogenic wedge, partly accomplished by the development of normal detachments (Fig. 3E). This stage, ca. 375-365 Ma, gave way to a regime of intracontinental deformation that progressed toward the more external parts of the orogen (Fig. 3, F and G) and lasted until 290 Ma (Martínez Catalán et al., 1996; Dallmeyer et al., 1997).

This relatively simple scenario is complicated by transcurrent movements and escape tectonics, not considered in this essentially cross-sectional model. However, the existence of DevonianCarboniferous foredeep basins on both sides of the Ibero-Armorican arc must be taken into account. Known as the Rhenohercynian and South Portuguese zones (Fig. 2), these realms are probably continuous all over the outer parts of the arc, and were at least partially floored by oceanic lithosphere, represented by the Lizard and BejaAcebuches ophiolites. The Lizard ophiolite has been dated as Early Devonian (Davies, 1984, $\mathrm{Sm}-\mathrm{Nd}$ in gabbro), and the Beja-Acebuches ophiolite is probably also Devonian (Oliveira, 1990). According to Franke (1989), the basins

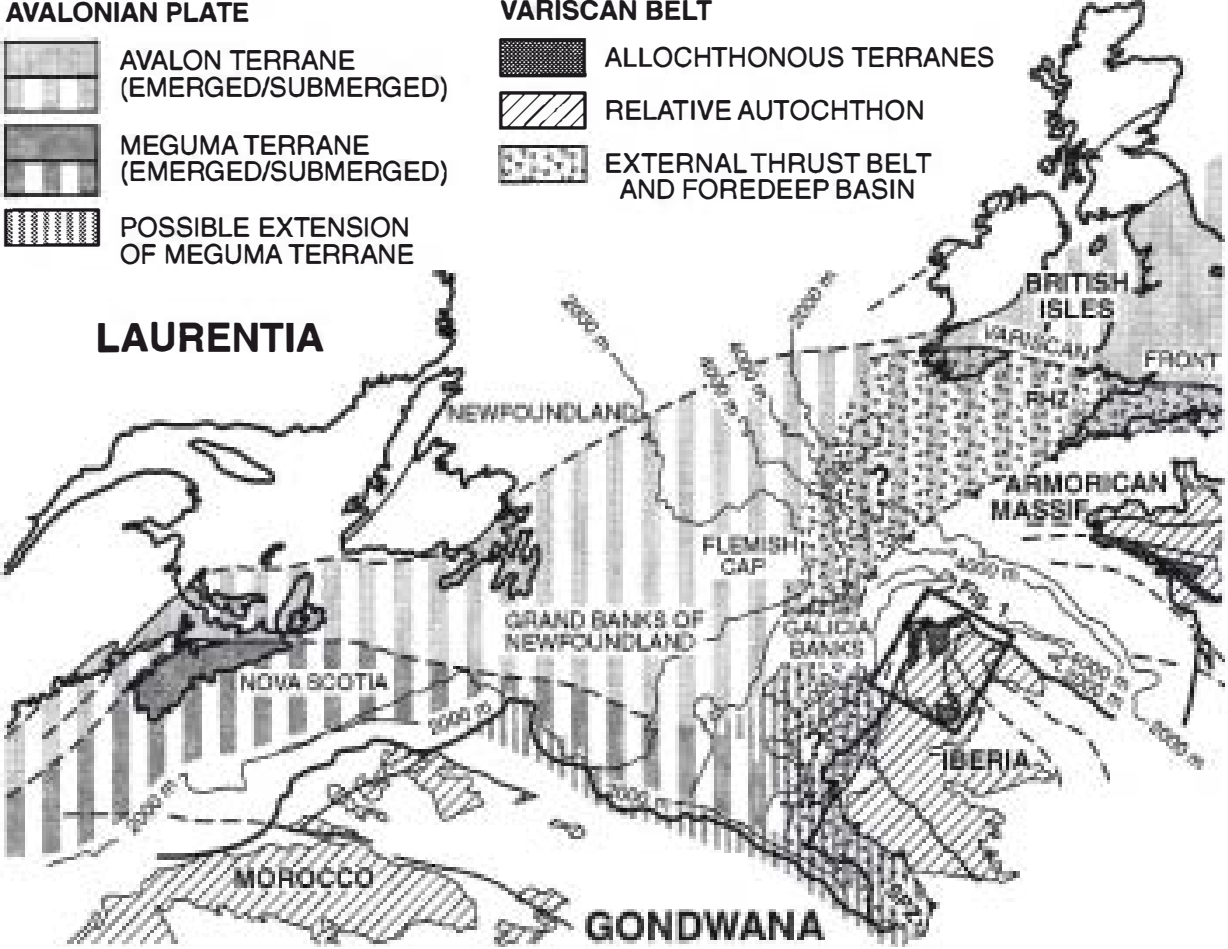

Figure 2. Reconstruction of Pangea around Iberia, based largely on Lefort (1989). RHZ-Rhenohercynian zone, SPZ-South Portuguese zone. Depths in meters refer to present-day isobaths.

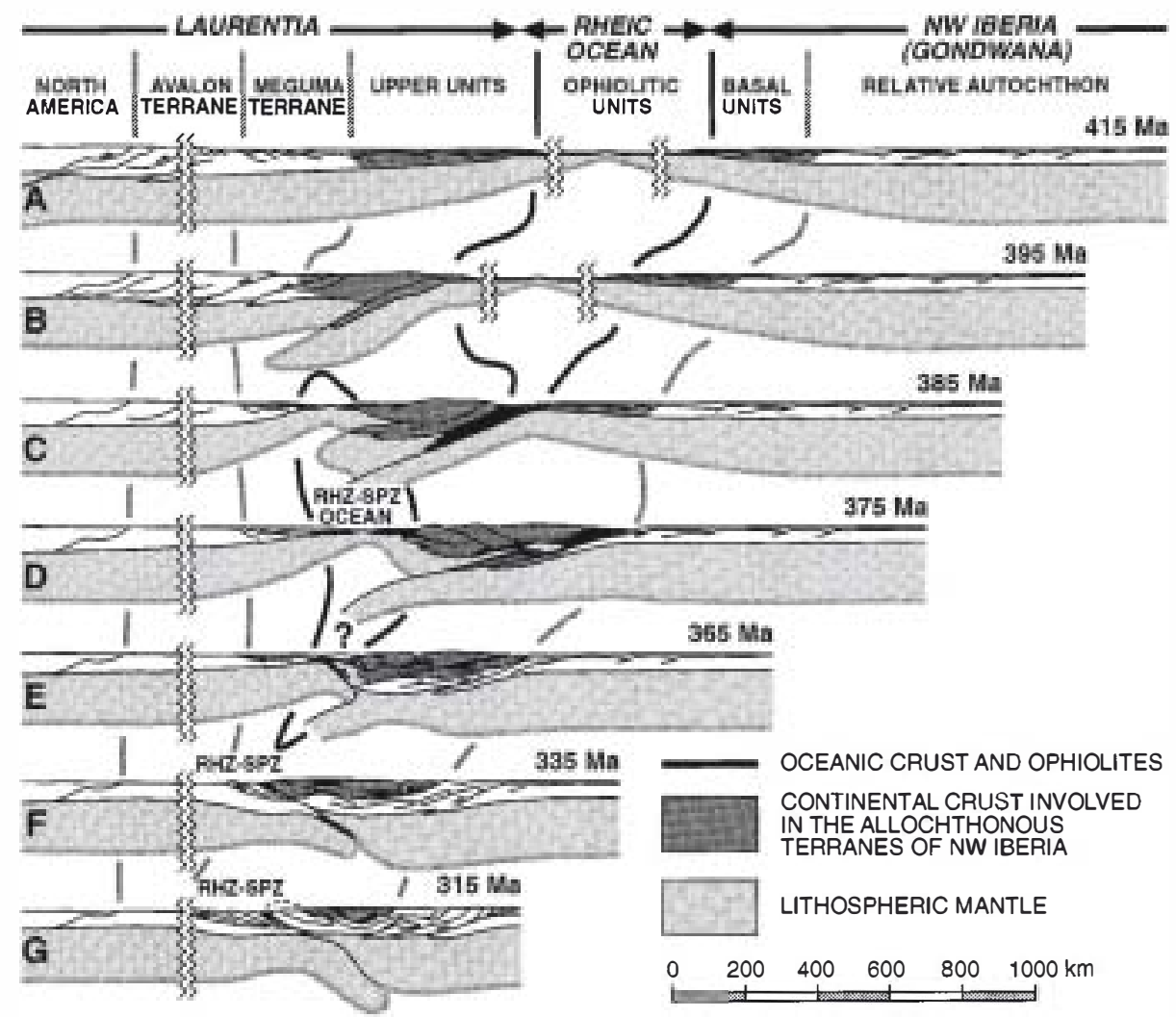

Figure 3. Accretionary evolution of the northwest lberian allochthonous terranes across a transverse from Iberia to Newfoundland. 
cannot be explained by early Paleozoic rifting because extension-related volcanism continued until the mid-Visean (see also Oliveira, 1990), a ime when the Rheic ocean was apparently already closed. We support the interpretation that they represent a back-arc extension related to the subduction of an intervening ocean (Floyd, 1984; Fonseca and Ribeiro, 1993).

In the light of our accretionary model, the foredeep basins were created inside the AvalonianMeguma crust, behind the active subduction zone responsible for the consumption of the Rheic ocean (Fig. 3, C and D). Subsequently, they were penetratively deformed by thnusts during the Carboniferous (Bames and Andrews, 1986; Fonseca and Ribeiro, 1993).

\section{CONCLUSIONS}

The upper units of the northwest Iberian allochthon, occurring in the hanging wall to the suture, are considered parts of the southeastern edge of the Meguma terrane, facing the Rheic ocean, whereas the ophiolitic units are remnants of this ocean, and the basal units, in the footwall to the suture, represent the conjugate outer margin of Gondwana. The ensemble underwent a progressiveaccretion to the continental margin of Laurentia that ended by the collision between this continent and Gondwana. The accretional history involved partial subduction of the opposite continental margins on both sides of the Rheic ocean.

\section{ACKNOWLEDGMENTS}

This study was funded by the Spanish agency Dirección General de lrvestigación Cientifica y Técnica, and forms part of projects PB94-1396-C02-01 and 02. We thank Barbara Knowles for help with the English version, and J. B. Murphy and C. W. Passchier for constructive review.

\section{REFERENCES CITED}

Arenas, R., Rubio Pascual, F. J., Díaz García, F., and Martínez Catalán, J. R., 1995, High-pressure micro-inclusions and development of an irverted metamorphic gradient in the Santiago Schists (-rdenes Complex, NW Iberian Massif, Spain): Evidence of subduction and syn-collisional decompression: Joumal of Metamorphic Geology, v. 13, p. $141-164$

Barnes, R. P., and Andrews, J. R., 1986, Upper Paleozoic ophiolite generation and obduction in South Comwall: Geological Society of London Joumal, v. 143, p. $117-124$

Cocks, L. R. M., and Fortey, R. A., 1988, Lower Palaeozoic facies and faunas around Gondwana, in Audley-Charles, M. G., and Hallam, A., eds., Gondwana and the Tethys: Geological Society [London] Special Publication, v. 37, p. 183-200.

Dallmeyer, R. D., and Keppie, J. D., 1987, Polyphase late Paleozoic tectonothermal evolution of the southwestern Meguma Terrane, Nova Scotia: Evidence from ${ }^{40} \mathrm{Ar} /{ }^{39} \mathrm{Ar}$ mineral ages: Canadiam Journal of Earth Sciences, v. 24, p. 1242-1254.

Dallmeyer, R. D., and Tucker, R. D., 1993, U-Pb zircon age for the Lagoaanigen gneiss, Morais Complex, Portugal: Tectonic implications: GeologicalSociety of London. Joumal, v. 150, p. 405-410.
Dallmeyer, R. D., Ribeiro, A., and Marques, F., 1991, Polyphase Variscan emplacement of exotic terranes (Morais and Bragança Massifs) onto Iberian successions: Evidence from ${ }^{40} \mathrm{Ar} /{ }^{39} \mathrm{Ar}$ mineral ages: Lithos, v. 27, p. 133-144.

Dallmeyer, R. D., Martinez Catalán, J. R., Arenas, R., Gil Ibarguchi, J. I., Gutiérrez-Alonso, G., Farias, P., Aller, J., and Bastida, F., 1997, Diachronous Variscan tectonothermal activity in the NW Iberian Massif: Evidence from ${ }^{40} \mathrm{Ar} /{ }^{39} \mathrm{Ar}$ dating of regional fabrics: Tectonophysics (in press).

Davies, G. R., 1984, Isotopic evolution of the Lizard Complex: Geological Society of London Joumal, v. 141 , p. 3-14.

Durning, G. R., Díaz García, F., Arenas, R., and Martínez Catalán, J. R., 1997, A Lower Devonian ophiolite in the allochthonous complexes of the Iberian Massif (Variscan Belt): U-Pb zircon protolith age from the Careón ophiolite: Terra Abstracts, v. 9, p. 100

Floyd, P., 1984, Chemical variation in Hercyniam basalts relative to plate tectonics: Geological Society of London Journal, v. 139, p. 507-522.

Fonseca, P., and Ribeiro, A., 1993, Tectonics of the Beja-Acebuches ophiolite: A major structure in the Iberian Variscan Foldbelt: Geologische Rundschan, v. 82, p. 440-447.

Franke, W., 1989, Tectonostratigraphic units in the Variscan belt of central Europe, in Dallmeyer, R. D., ed., Terranes in the Circum-Atlantic Paleozoic orogens: Geological Society of America Special Paper 230, p. 67-90.

Gebauer, D., 1993, Intra-grain zircon dating within the Iberian Massif: Ollo de Sapo augengneisses, bimodal gneisses from the Massif de Gulleries (Grona), graywacke of the Tentudía Group (Serie Negra, SW Spain) and the HP/HT-rock association at Cabo Ortegal (Galicia): Comunicaçoes da XII Reuniao de Geologia do @este Peninsular, Universidade de Evora, Evora, Portugal, v. 2 , p. $41-46$

Hatcher, R. D., 1989, Tectonic synthesis of the U.S. Appalachians, in Hatcher, R. D., Thomas, W. A., and Viele, G.W., eds., The Appalachian-Quachita Orogen in the UnitedStates: Boulder, Colorado, Geological Society of America, The geology of North America, v. F-2, p. 511-535.

Keppie, J. D., and Dallmeyer, R. D., 1987, Dating ranscurrent terrane accretion: An exannle from the Meguma and Aval on composite terrames in the northem Appalachians: Tectonics, v. 6, p. $831-847$

Krogh, T. E., and Keppie, J. D., 1990, Age of detrital zircon and titanite in the Meguma Group, southem NovaScotia, Canada: Clues to the origin of the Meguma terrane: Tectonophysics, v. 177, p. 307-323.

Kuijper, R. P., 1980, Precambrian U-Pb zircon ages from Western Galicia(NWSpain): Earth-Science Reviews, v. 16, p. 313-316.

Lancelot, J. R., Allegret, A., and Iglesias-Ponce de León, M., 1985, Qutline of Upper Precambrian and lower Paleozoic evolution of the Iberian Peninsula according to U-Pb dating of zircons: Earth and PlanetaryScience Letters, v. 74, p. 325-337.

Lefort, J. P., 1989, Basement correlation across the North Atlantic: Berlin, Germany, Springer, 148p.

Martínez Catalán, J. R., Arenas, R., Díaz García, F., Rubio Pascual, F. J., Abati, J., and Marquínez, J., 1996, Vaniscan exhumation of a subductedPaleozoic continental margin: The basal units of the
Ordenes Complex, Galicia, NWSpain: Tectonics, v. 15, p. 106-121.

Murphy, J. B., Nance, R. D., Keppie, J. D., Dostal J., and Cousens, B. L., 1995, Odyssey of West Avalonia: Isotopic constraints for Late Proterozoic III-Early Silurian Paleogeography, in Hibbard, J. P., Vam Staal, C. R., and Cawo od, P. A., eds., Cument perspectives in the Appalachiam-Caledonian orogen: Geological Association of CanadaSpecial Paper, v. 41, p. $227-237$.

-liveira, J. T., 1990, South Portuguese Zone. Stratigraphy and synsedimentary tectonism, in Dallmeyer, R. D., and Martínez García, E., eds., Pre-Mesozoic geology of Iberia: Berlin, Germany, Springer, p. 334-347.

Peucat, J. J., Bernard-Griffiths, J., Gil Ibarguchi, J. I., Dallmeyer, R. D., Menot, R. P., Comichet, J., and Iglesias Ponce de León, M., 1990, Geochernical and geochronological cross section of the deep Variscan crust: The Cabo Ortegal high-pressure nappe (northwestem Spain): Tectonophysics, v. 177, p. $263-292$.

Quinlan, G. M., Hall, J., Williams, H., Wright, J. A., Cohnan-Sadd, S. P., @'Brien, S. J., Stockmal, G.S., and Marillier, F., 1992, Lithoprobe onshore seismic reflection ransects across the Newfound1and Appalachians: Canadian Joumal of Earth Sciences, v. 29, p. 1865-1877.

Ribeiro, M. L., and Floor, P., 1987, Magmatismo peralcalino no Maciço Hespérico: sua distribução e significado geodinámico, in Bea, F., Camnicero, A., Gonzalo, J. C., López-Plaza, M., and RodríguezAlonso, M. D., eds., Geología de los granitoides y rocas asociadas del Macizo Hespérico: Madrid, Spain, Rueda, p. 211-221.

Santos Zalchegui, J. F., Schärer, U., and Gil Ibarguchi, J. I., 1995, Isotope constraints on the age and origin of magmatism and metamorphism in the Malpica-Tuy allochthon, Galicia, NW Spain: Chernical Geology, v. 121, p. 91-103.

Santos Zalduegui, J. F., Schärer, U., Gil Ibarguchi, J. I., and Girardeall, J., 1996, Origin and evolution of the Paleozoic Cabo Ortegal ultramaficmafic complex (NW Spain): U-Pb, Rb-Sr, and $\mathrm{Pb}-\mathrm{Pb}$ isotope data: Chemical Geology, v. 129, p. 281-304.

Schäfer, H. J., Gebauer, D., Gil Ibarguchi, J. I., and Peucat, J. J., 1993, Ion-microprobe U-Pb zircon dating on the HP/HT Cabo Ortegal Complex (Galicia, NWSpain): Preliminary results: Terra Abstracts, v. 5, p. 22.

Van Calsteren, P. W. C., and Den Tex, E., 1978, An early Paleozoic continental rift system in Galicia (Spain), in Ramberg, I. B., and Neumann, E. R., eds., Tectonics and geophysics of continental rifts: Dordrecht, Netherlands, Reidel, p. 25-132.

Van Calsteren, P. W. C., Boelrijk, N. A. I. M., Hebeda, E. H., Priem, H. N. A., Den Tex, E., Verdurmen, E. A. T. H., and Verschure, R. H., 1979, Isotopic dating of older elements (including the Cabo Ortegal mafic-ultramafic complex) in the Hercynian Orogen of NWSpain: Manifestations of a presumed early Paleozoic Mantle-plume Chemical Geology, v. 24, p. 35-56. 